Annals of Warsaw University of Life Sciences - SGGW

Land Reclamation No 48 (3), 2016: 201-220

(Ann. Warsaw Univ. of Life Sci. - SGGW, Land Reclam. 48 (3), 2016)

\title{
Nonlinear dynamic properties of silty clay from Warsaw area
}

\author{
WOJCIECH SAS, KATARZYNA GABRYŚ, EMIL SOBÓL, \\ ALOJZY SZYMAŃSKI \\ Faculty of Civil and Environmental Engineering, Warsaw University of Life Sciences - SGGW
}

\begin{abstract}
Nonlinear dynamic properties of silty clay from Warsaw area. In this work, the small-strain and nonlinear dynamic properties of silty clay samples were studied by means of the lowand high-amplitude resonant column (RC) tests at various mean effective stresses $\left(p^{\prime}\right)$. The tested specimens were collected from the centre of Warsaw, district Śródmieście. Initially, the low-amplitude tests (below $0.001 \%$ ) were conducted. Subsequently, the nonlinear testing was performed, at shearing strains greater than $0.001 \%$. These tests were carried out in order to receive the dynamic properties of silty clay specimens in the nonlinear shear strain range. The small-strain material damping ratios $\left(D_{\min }\right)$ of silty clay samples were also measured during the low-amplitude resonant column testing. The results show that increasing shear strain $(\gamma)$ above the elastic threshold $\left(\gamma_{t e}\right)$ causes a decrease of the shear modulus $(G)$ and normalized shear modulus $\left(G / G_{\max }\right)$ of analyzed soil samples. Simultaneously, it is observed a increase of its damping ratio $(D)$ and normalized damping $(D /$ $\left./ D_{\min }\right)$ with increasing shear strain $(\gamma)$. Predictive equations for estimating normalized shear modulus and material damping of silty clay soils were presented here as well. The equations are based on a modified hyperbolic model and a statistical analysis of the RC tests results. The influence of unloading process on dynamic properties of the tested material was also discussed in the paper.
\end{abstract}

Key words: nonlinear dynamic properties, silty clay, laboratory tests, resonant column apparatus

\section{INTRODUCTION}

The behaviour of soil and rock materials due to shearing motions is one of the key properties that generally impacts the geotechnical engineering design under various dynamic loadings. Dynamic loading and subsequent response of the subsoil must be described in the context of wave propagation. The properties governing the behaviour of soil subjected to dynamic loading are called dynamic soil properties (Kramer 1996). In order to investigate the dynamic behaviour of soil under shearing loads, two parameters, i.e. the shear modulus $(G)$ and the material damping ratio $(D)$ are most frequently calculated (Das 1993). These properties are measured in the linear and nonlinear strain ranges. The shear modulus is a parameter that describes the stiffness of geotechnical materials and it is directly related to the deformation under shearing loads. The material damping ratio, on the other hand, represents dissipation of energy during each cycle of shearing motions. Stiffness and damping can be determined from both laboratory and in situ tests. The laboratory measurements are well-suited for parametric studies, such as the effects of stress state and strain amplitude. In the field, however, seismic testing is used in order to evaluate the shear wave velocity at small strains $\left(V_{S}\right)$, through which the small strain shear modulus $\left(G_{\max }\right)$ is calculated. 
From the past studies, it is known that the dynamic shearing behaviour of geotechnical materials can be divided into two parts, according to the range of shear strain $(\gamma)$. These are the following: the small-strain range and the nonlinear range. Small strains, when shear strains are typically below $0.001 \%$, do not cause any significant nonlinear stress-strain behaviour in the soil. In the small-strain range, the shear modulus as well as the material damping ratio are constant; at this strain level they are assumed to be the maximum $-G_{\max }$, and the minimum - $D_{\text {min. }}$. Beyond the small-strain range, the shear modulus decreases and the material damping increases with increasing shear strain in the nonlinear range. The nonlinear dynamic properties of soils are very useful in many geotechnical analyses. In particular, they are extremely relevant in the analyses relying on the rigorous understanding of the mechanical behaviour of cyclically loaded soils, such as those affected by earthquakes, waves or wind loads (Carraro 2015). The nonlinear stiffness and damping characteristics impact significantly as well on the design of various engineering activities undertaken in cohesive soils (Gasparre 2014).

For the proper evaluation of the dynamic properties of soil resonant column tests are widely used in the world (Cascante et al. 2005). The resonant column device is capable of determining the dynamic properties at shear strain levels from very low $\left(\gamma<10^{-6}\right)$ to mid shear strain level $\left(\gamma<10^{-3}\right)$. Moreover, the shear modulus and the damping ratio are measured independently of each other, contrary to the principle of causality and excessive number of cycles are imposed
(Khan et al. 2008). The resonant column apparatus (RCA) provides more consistent test results than any other device (ASTM 2000) and, moreover, its results are accurate and reliable.

The purpose of this study was to verify what are the nonlinear dynamic properties of selected cohesive material and how they change. The paper contains the results of laboratory experiments received from resonant column tests carried out on silty clay samples from the centre of Warsaw, the capital of Poland. The authors tried to evaluate as well the influence of certain parameters, such as: the shear strain $(\gamma)$, the mean effective stress $\left(p^{\prime}\right)$ and the unloading process, on the shear modulus and the material damping ratio in the small-strain range and the nonlinear strain range.

\section{DYNAMIC PROPERTIES OF SOIL - GENERAL INFORMATION}

The dynamic properties of soil describe how soil behaves under dynamic loading and also under static loading at small to moderate strains (Kacar 2014). Most studies of the dynamic properties of soil in shear cover two, three of four generalized strain ranges. The three strain ranges most often investigated by dynamic testing in the laboratory are: (1) the small-strain linear range, (2) the nonlinear "elastic" range and (3) the moderately nonlinear range. These strain ranges are illustrated in Figure 1. The small-strain linear range is represented by shear strains at or below the elastic threshold strain $\left(\gamma_{t e}\right)$. In the small-strain range, $G_{\max }$ and $D_{\min }$ are independent of shear strain. The normalized shear 


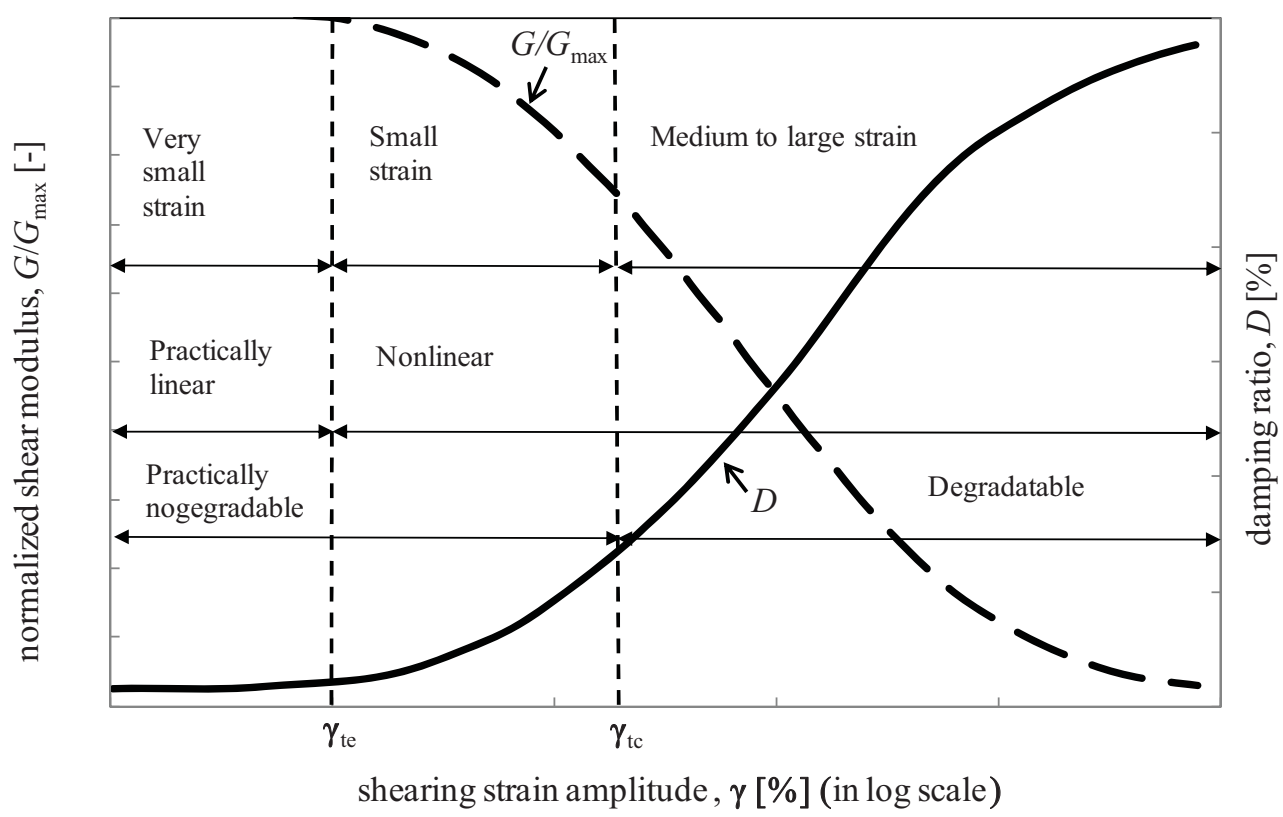

FIGURE 1. Normalized modulus and damping curves with different zones of cyclic shearing strain amplitude for soil (Vucetic 1994)

modulus $\left(G / G_{\max }\right)$ is equal to 1.0 in this strain range. Above $\gamma_{t e}$ in the nonlinear "elastic" range, $G$ and $G / G_{\max }$ decrease with increasing shear strain, whereas $D$ increases with increasing shear strain (Fig. 1). The upper bound of the second strain range is denoted by the cyclic threshold strain $\left(\gamma_{t c}\right)$. At strains above $\gamma_{t c}$, the tendency for volume change begins and this effects as well as changes in the material skeleton. Above the cyclic threshold strain the term "elastic" is no longer used due to the permanent changes in the granular material. In the third strain range, the moderately nonlinear range, dynamic properties of soil are changing significantly with shear strains. The value of the elastic threshold strain varies with soil type, but $\gamma_{t e}=$ $=0.001 \%$ can be assumed as a representative value, provided that the soil type is unknown and the confining pressure is around $1.0 \mathrm{~atm}$.

Many other factors can affect the dynamic properties of soil. For example, confining pressure, void ratio, geologic age, cementation, over-consolidation, plastic index, strain rate and number of loading cycles may have a significant impact on $G, D$ and on the nonlinear dynamic properties (Hardin and Drnevich 1972). The nonlinear dynamic properties are usually described by the modulus reduction and damping curves, which are of importance for the response analysis of several dynamic problems especially for high strain cases such as strong ground motion caused by horizontal force due to strong earthquake (Bai 2011).

The cyclic threshold strain $\left(\gamma_{t c}\right)$ and the reference strain $\left(\gamma_{r}\right)$, where the $G /$ $/ G_{\max }$ is equal to 0.5 , are effective strain 
levels for comparison of mild ("elastic") and moderate nonlinearity.

Seed et al. (1986) presented a study which showed that sandy soils behave more linearly than gravelly soils in the mild and moderate nonlinear ranges of shear strains. This difference in response means that sandy soils have larger values of $\gamma_{t c}$ and $\gamma_{r}$ than gravelly soils. Tanaka et al. (1978) showed how isotropic confining pressure $\left(\sigma_{0}^{\prime}\right)$ and gravel content influenced the nonlinear behaviour of gravelly soil. He stated that both curves $G / G_{\max }-\log \gamma$ and $D-\log \gamma$ move to the right direction, towards higher shear strains, and $\gamma_{r}$ increases when confining pressure increases and gravel content decreases. Such behaviour would be an indicator of greater linearity. Darendeli (2001), by contrast, introduced the modified hyperbolic model in order to present the nonlinear behaviour of sandy and gravelly soils. The normalized shear modulus $\left(G / G_{\max }\right)$ equation is as follows:

$$
\frac{G}{G_{\max }}=\frac{1}{1+\left(\frac{\gamma}{\gamma_{r}}\right)^{a}}
$$

where:

$a$ - curvature coefficient.

Menq (2003), on the other hand, found that another main factor which affects the nonlinear dynamic properties of non-cohesive soils is the uniformity coefficient $\left(C_{u}\right)$. With increasing $C_{u}$, sandy and gravelly soils behave more nonlinearly and the reference strain decreases. He proposed as well how to calculate the parameters in Darendeli's modified hyperbolic model (Eq. 1):

The modified hyperbolic model can be apply as well to describe the material damping ratio [Wang 2015]. The equation that can be used to represent each hyperbolic curve in the $D-\log \gamma$ relationship is:

$\frac{D}{D_{\min }}=1+\left(\frac{\gamma}{\gamma_{r, D}}\right)^{b}$

where:

$\gamma_{r, D}=D / D_{\min }=2$

$b$ - fitting parameter.

It must be remembered that $\gamma_{r, D}$ and $b$ are not related to $\gamma_{r}$ and $a$ for the $G / G_{\max }$ $-\log \gamma$ relationship.

\section{MATERIAL AND METHOD}

\section{Resonant column method}

In these research, the resonant column (RC) testing system was successfully employed, as a prime tool to investigate the dynamic characterization of soil specimens in the shear strain range of $1.0^{-5}$ to $1.0^{-2} \%$. The basic principle in performed $\mathrm{RC}$ testing was to vibrate a cylindrical specimen of material in first-mode torsional motion. The authors adapted the simplest configuration which involved a soil specimen that is free to move in torsional motion at the top and is fixed by a rigid base pedestal at the bottom. Sinu- 
soidal torsional excitation was applied to the top of the specimen over a range of frequencies in a downward, stepped-wise of the specimen was then recorded and a dynamic response curve was created (Fig. 2). The used RC configuration is a fixed-free RC test; because the top of the specimen was freely vibrating while the bottom of the specimen remained fixed (remained stationary) (Sas and Gabryś 2012, Gabryś et al. 2013, Sas et al. 2015a).

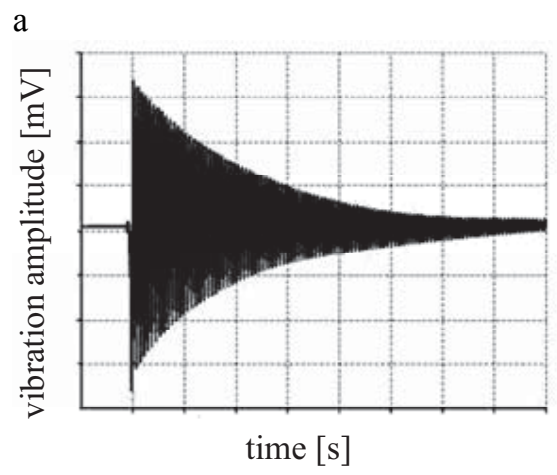
sweep. The torsional motion of the top

RC Apparatus, as well as the calibration methods, are presented in other authors' publications (Gabryś et al. 2013, Gabryś 2014).

The shear modulus $(G)$ was calculated from the frequency response curve. The frequency response curve is "bell-like" and has a peak at the first-mode resonant frequency (Fig. 2b). The relationships between the resonant circular frequency $\left(\omega_{r}\right)$ and the shear wave velocity $\left(V_{S}\right)$, as well as the dependence of the shear modulus on e.g. $V_{S}$ in the wave propa-

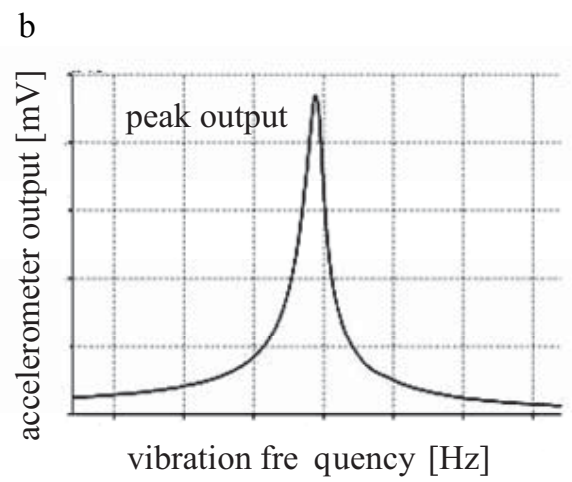

FIGURE 2. Typical resonant column test signal in (a) time and (b) frequency domain

In Figure 3, a photograph of the resonant column device employed by the authors for the experiments discussed here is shown. The apparatus is composed of four basic subsystems, which are as follows: (1) a confinement system that applies confining pressure to the specimen, (2) a drive system that is used to apply sinusoidal torsional excitation at the top of the specimen, (3) a height monitoring system that is used to measure the height-change of the specimen during confinement, and (4) a motion monitoring system that is used to measure the torsional response at the top of the specimen. The constructions details of the

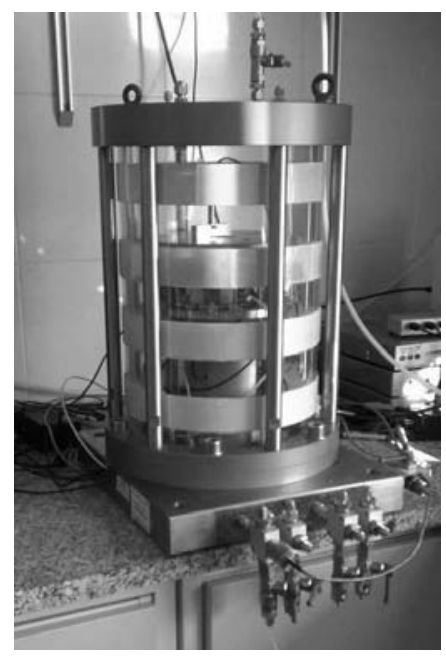

FIGURE 3. Exemplary photograph of the resonant column device 
gation theory, which was necessary to calculate $G$, are discussed in (GDS 2010, Bai 2011, Gabryś 2014, Wang 2015). The material damping ratio $(D)$ was obtained from the free-vibration decay curve (Fig. 2a), regardless of the magnitude of shear strains. In both, the linear and the nonlinear strain range, only this one method was used to evaluate $D$. The free-vibration decay curve was received by suddenly stopping the current to the drive soils during the constant vibration at the resonant frequency (Gabryś et al. 2015, Soból et al. 2015). The damping ratio was calculated from the logarithmic decrement, as presented in (Sas et al. 2015b).

\section{Testing material}

Two soils were tested in this study. They were both silty clay ( $\mathrm{siCl})$, in accordance with Eurocode 7 (EN 1997), collected from the neighbourhood of the streets Jana Pawła and Grzybowska, test field in Sródmieście district, Warsaw (Gabryś et al. 2015). The specimens had quite similar particle size distribution (Fig. 4), however they were extracted from different depth, approximately of $6.0 \mathrm{~m}$ (sample A) and $8.5 \mathrm{~m}$ (sample B). Basic index properties of the specimens tested are shown in Table 1.

\section{Experimental program}

Initial specimen setup, saturation and consolidation, were conducted according to Head (1986). All specimens tested had a Skempton's parameter $(B)$ equal to or higher than 0.97 . Resonant column testing was conducted in general accordance with ASTM D 4015-92 (2000). Details about the experimental methods used are discussed in details in (Gabryś et al. 2015, Sas et al. 2015a).

In this study, typical drained resonant column tests at constant confining stress were conducted, primarily to assess the non-linearity in the shear modulus and

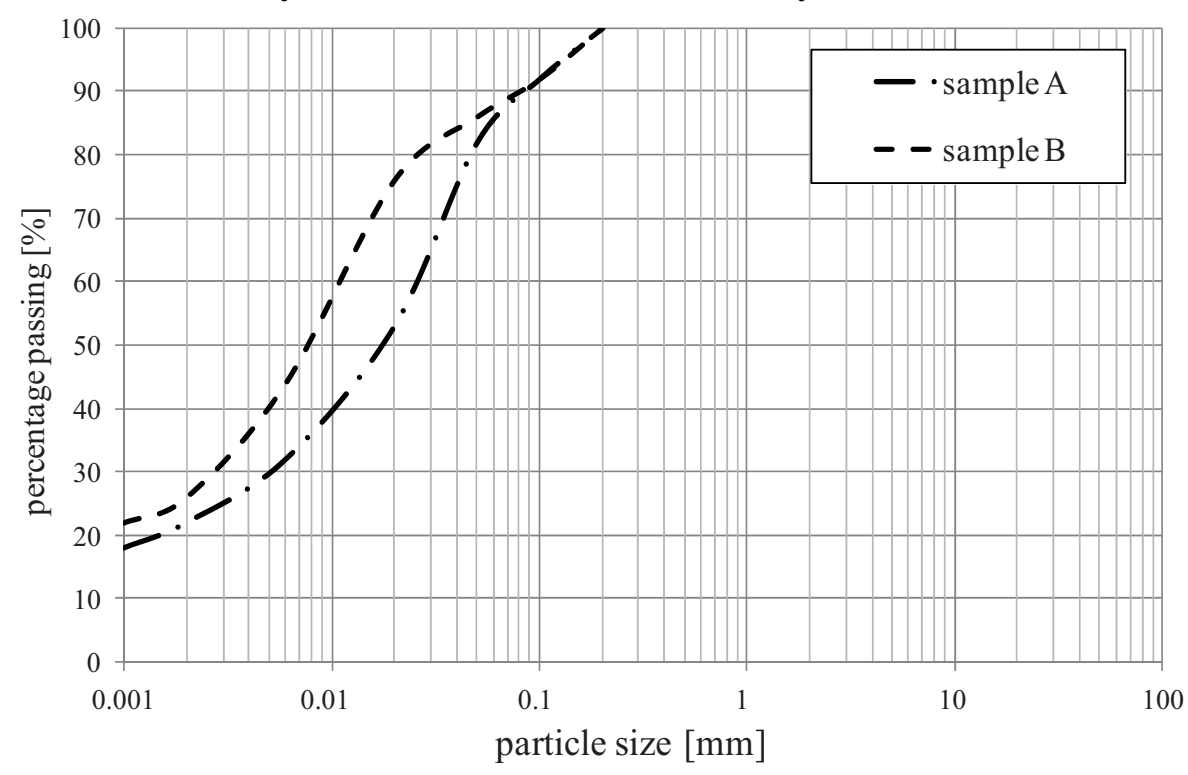

FIGURE 4. Grain size distribution of tested specimens 
TABLE 1. Index properties and parameters of specimens tested

\begin{tabular}{cccc}
\hline Parameter & Unit & $\begin{array}{c}\text { Sample A } \\
\text { value }\end{array}$ & $\begin{array}{c}\text { Sample B } \\
\text { value }\end{array}$ \\
\hline$w$ & $\%$ & 17.52 & 16.55 \\
$w_{P}$ & $\%$ & 17.14 & 19.49 \\
$w_{L}$ & $\%$ & 33.00 & 44.30 \\
$I_{P}$ & $\%$ & 15.86 & 24.81 \\
$I_{L}$ & $(-)$ & 0.02 & -0.12 \\
$\mathrm{I}_{C}$ & $(-)$ & 0.98 & 1.12 \\
$\rho$ & $\mathrm{kg} / \mathrm{m}^{3}$ & 2140 & 2030 \\
\hline
\end{tabular}

Explanations: $w$ is the water content, $w_{P}$ the plastic limit, $w_{L}$ the liquid limit, $I_{P}$ the plastic index, $I_{L}$ the liquidity index, $I_{C}$ the consistency index and $\rho$ is the mass density.

the damping ratio with increasing shear strain. Solid cylindrical specimens, with nominal diameter and height equal to 70 and $140 \mathrm{~mm}$, respectively, were subjected to various isotropic mean effective stress ( $\left.p^{\prime}\right)$. For sample A, $p^{\prime}$ amounted to $30,120,180,240,360$ and $410 \mathrm{kPa}$, whereas for sample B, proportionately, $85,170,225$ and $310 \mathrm{kPa}$. Resonant frequencies ranged from $45.5 \mathrm{~Hz}$ for small strain measurements at $30 \mathrm{kPa}$ effective stress to $142.1 \mathrm{~Hz}$ for large strain measurement at $410 \mathrm{kPa}$ - sample $\mathrm{A}$. In the case of sample $\mathrm{B}$, resonant frequencies ranged from $82.8 \mathrm{~Hz}$ for small strain measurements at $85 \mathrm{~Pa}$ effective stress to $135.4 \mathrm{~Hz}$ for large strain measurement at $310 \mathrm{kPa}$.

Both, the low-amplitude resonant column (hereinafter referred to RC-LA) tests, shearing strains below $0.001 \%$, and the high-amplitude resonant column (RC-HA) tests, $\gamma>0.001 \%$, were performed to evaluate the dynamic properties of the silty clay samples. The test procedure was divided into four parts, (1) the loading RC-LA tests, (2) the loading RC-HA tests, (3) the unloading RC-LA tests and (4) the unloading RC-HA tests. The confining pressures were increased in steps and at each pressure, first, the loading and, next, the unloading tests were carried out. The RC-LA tests were performed in order to receive the small-strain dynamic properties of the tested material, whereas the RC-HA tests were performed to investigate the nonlinear behaviour of the specimens. The RC-HA test began immediately after the RC-LA test to minimize time effects on the dynamic properties. For the RC-LA tests the range of the output amplitude, indicated here as $A$, was as follows: $0.001-0.01 \mathrm{~V}$, while for the RC-HA tests $A$ was bigger than $0.01 \mathrm{~V}$. The RC-HA tests were finished when the output amplitude was equal to $0.6 \mathrm{~V}$. The results from the experimental program are presented and discussed next.

\section{RESULTS}

\section{Small-strain dynamic properties}

The variations in the small-strain shear modulus $\left(G_{\max }\right)$ and the small-strain material damping $\left(D_{\min }\right)$ with mean effective stress $\left(p^{\prime}\right)$ from $\mathrm{RC}$ testing of sample A and B are presented in Table 2. Moreover, the small-strain dynamic properties of sample A obtained during unloading process are listed here as well. 
TABLE 2. Comparative summary of $R C$ small strain tests results of sample A and $\mathrm{B}$

\begin{tabular}{|c|c|c|c|c|c|c|c|c|c|c|}
\hline \multirow{2}{*}{ S ample } & \multirow{2}{*}{$\begin{array}{c}\text { Mean } \\
\text { effective } \\
\text { stress, } p^{\prime} \\
{[\mathrm{kPa}]}\end{array}$} & \multicolumn{4}{|c|}{ Loading } & \multirow{2}{*}{$\begin{array}{c}\text { Mean } \\
\text { effective } \\
\text { stress, } p^{\prime} \\
{[\mathrm{kPa}]}\end{array}$} & \multicolumn{4}{|c|}{ Unloading } \\
\hline & & $\begin{array}{c}\text { shearing } \\
\text { strain, } \\
\gamma[-]\end{array}$ & $G_{\max }[\mathrm{MPa}]$ & $\begin{array}{c}\text { Shearlng } \\
\text { strain, } \\
\gamma[-]\end{array}$ & $D_{\min }[\%]$ & & $\begin{array}{c}\text { shearlng } \\
\text { strain, } \\
\gamma[-]\end{array}$ & $G_{\max }[\mathrm{MPa}]$ & $\begin{array}{c}\text { shearnng } \\
\text { strain, } \\
\gamma[-]\end{array}$ & $D_{\min }[\%]$ \\
\hline \multirow{6}{*}{ A } & 30 & $4.24 \mathrm{E}-06$ & 46.27 & $7.20 \mathrm{E}-06$ & 1.21 & & & & & \\
\hline & 120 & $2.28 \mathrm{E}-06$ & 89.50 & $5.73 \mathrm{E}-06$ & 1.15 & 360 & $9.08 \mathrm{E}-06$ & 189.68 & $2.17 \mathrm{E}-06$ & 0.96 \\
\hline & 180 & 4.64E-06 & 118.98 & 4.64E-06 & 1.10 & 300 & $2.28 \mathrm{E}-06$ & 177.15 & $3.36 \mathrm{E}-06$ & 1.00 \\
\hline & 240 & $5.33 \mathrm{E}-06$ & 140.72 & $2.77 \mathrm{E}-06$ & 1.07 & 240 & $6.98 \mathrm{E}-06$ & 160.52 & $3.60 \mathrm{E}-06$ & 1.07 \\
\hline & 360 & $2.25 \mathrm{E}-06$ & 171.94 & $2.25 \mathrm{E}-06$ & 1.00 & 180 & $5.40 \mathrm{E}-06$ & 143.06 & 4.17E-06 & 0.99 \\
\hline & 410 & $3.01 \mathrm{E}-06$ & 195.69 & $2.05 \mathrm{E}-06$ & 0.97 & 120 & $6.31 \mathrm{E}-06$ & 115.56 & $4.88 \mathrm{E}-06$ & 1.08 \\
\hline \multirow{4}{*}{ B } & 85 & $2.57 \mathrm{E}-05$ & 71.04 & 7.91E-05 & 1.70 & & & & & \\
\hline & 170 & $1.41 \mathrm{E}-05$ & 110.30 & $7.10 \mathrm{E}-05$ & 1.52 & & & & & \\
\hline & 255 & $1.14 \mathrm{E}-05$ & 129.85 & 2.15E-05 & 1.44 & & & & & \\
\hline & 310 & $9.68 \mathrm{E}-06$ & 162.24 & $2.56 \mathrm{E}-05$ & 1.27 & & & & & \\
\hline
\end{tabular}

These properties of silty clay soils were measured during low-amplitude RC testing, as indicated in Table 2 by the strain values $\gamma$.

Small-strain shear modulus of analyzed soils increase with increasing $p^{\prime}$, just as shown in numerous previous studies. For sample A, the biggest increase of $G_{\max }$, i.e. around $50 \%$, is noted for the second effective pressure ( $\left.p^{\prime}=120 \mathrm{kPa}\right)$, while the smallest increase, i.e. around $12 \%$, for the highest $\left(p^{\prime}=410 \mathrm{kPa}\right)$. Initially, a big difference between the applied pressures $(90 \mathrm{kPa})$ gives a large change in the value of $G_{\max }$, then when this difference is constant $(60 \mathrm{kPa})$, the changes in $G_{\max }$ are close to each other and are approximately $15-20 \%$. For sample B, about $36 \%$ increase in the value of $G_{\max }$ is observed for the first mean effective stress increase. Further changes of $G_{\max }$ amount approximately 15-20\%. From the results of $D_{\min }$, it can be concluded that $D_{\min }$ decreases with increasing $p^{\prime}$, although, for sample A, this decline is of the order of $3-5 \%$ and, for sample B, of the order of $11-13 \%$.
From the analysis of the unloading results, the decrease of $G_{\max }$ and simultaneous increase of $D_{\min }$ it is observed. The reduction in values of $G_{\max }$ ranges from 6 to $19 \%$ with the decrease of $p^{\prime}$. The increase in values of $D_{\min }$, however, amounts from 4 to $9 \%$ with the decrease of $p^{\prime}$.

\section{Nonlinear dynamic properties - shear modulus}

The high-amplitude resonant column (RC) tests were performed in order to obtain the dynamic properties of the silty clay specimens in the nonlinear shear strain range. These tests were conducted at various mean effective stresses $\left(p^{\prime}\right)$ listed in Figures 5 and 6. In the above-mentioned figures variations of the shear modulus $(G)$ with the shear strain $(\gamma)$ are presented. Moreover, they show the results from both, the RC-LA tests, when $G$ is constant and strain independent, and the RC-HA tests, while strong non-linearity and dependence on strain level is evident. 
It can be seen that for analyzed soils, at the same shearing strain level, the shear modulus increases with increasing effective pressure. The distance in $G$ under various $p$ ' decreases with increasing shearing strain amplitude, which implies that the shearing strain amplitude may eliminate the influence of the mean effective stress on the shear modulus at very high strain level.

It should be noted that during unloading process the higher values of soil stiffness are received (Fig. 5b). The stiffness degradation curves take therefore the higher positions in comparison to the same curves but obtained while loading stage. The differences between $G_{\text {unloading }}$ and $G_{\text {loading }}$ varies in the range from 10 up to $30 \%$ for the stress from 120 to $360 \mathrm{kPa}$, wherein the higher difference value $(\Delta G \cong 30 \%)$ corresponds to $p^{\prime}=120 \mathrm{kPa}$.

To eliminate the effect of $G_{\max }$ on the nonlinear shear modulus behaviour, the variations in the normalized shear modulus $\left(G / G_{\max }\right)$ with the shear strain $(\gamma)$ from RC testing of specimen A and B are presented in Figure 7. It can be seen that both samples have the same values of $G /$ $/ G_{\max }(1.0)$ when the shear strain is in the linear small-strain range. When the normalized shear modulus begins to exhibit the nonlinearity, this strain is taken as the elastic threshold strain $\left(\gamma_{t e}\right)$. Value of $\gamma_{t e}$ was defined as the strain at which the ratio of the modulus to maximum modu-

a

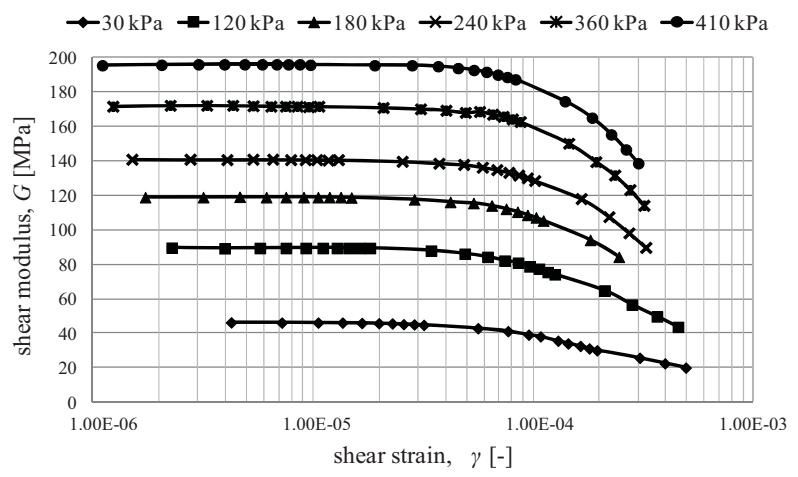

$\mathrm{b}$

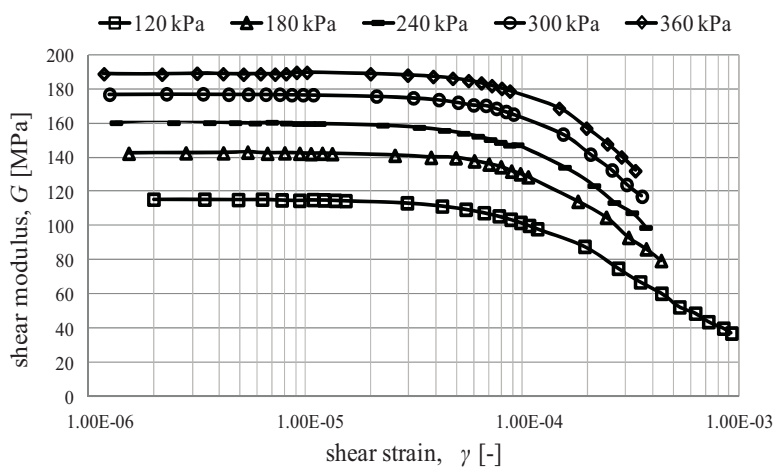

FIGURE 5. Shear modulus versus shear strain for sample A during (a) loading and (b) unloading process 


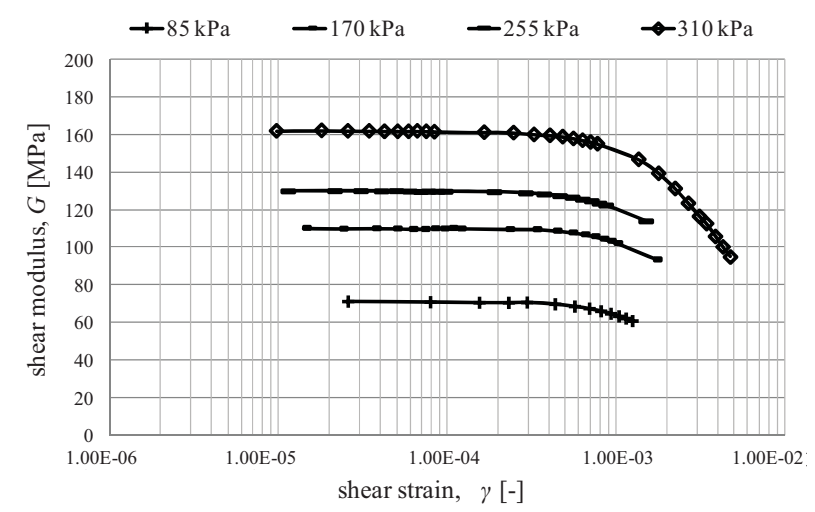

FIGURE 6. Shear modulus versus shear strain for sample B during loading process

lus is 0.99 by Vucetic (1994). The average elastic threshold strain for sample A is $2.86 \mathrm{E}-05$ and for sample $\mathrm{B}-3.56 \mathrm{E}-04$. Sample B, taken from the greater depth $(8.5 \mathrm{~m})$, has higher value of $\gamma_{t e}$ than sample A, collected from $6.0 \mathrm{~m}$, which also corresponds to the higher values of $G /$ $/ G_{\max }$. From Figure 7 , it can be observed that for sample B the linear elastic range is bigger than for sample A. This finding suggests that sample B is characterized by greater stiffness in relation to sample A.

For the purpose of practical application, Hardin and Drnevich (1972) suggested 2.5E-05 as the elastic threshold strain to determine $G_{\max }$. Some researchers (Hardin and Richart 1963, Isenhower and Stokoe 1981, Shen et al. 1985, Qian et al. 1993) has reported that when the shearing strain amplitude is less than $1.0 \mathrm{E}-05$, shearing strain influence on the shear modulus of various soils is negligible. For these studies, it is seen that the reduction of $G_{\max }$ is less than $1 \%$ for $\gamma_{t e}$ of slightly greater value than these above-mentioned. Nevertheless, the small-strain shear modulus of tested soils should be determined at the shear strain below 1.0E-05 to avoid e.g. appreciable change in soil structure.
If the shearing strain amplitude exceeds the cyclic threshold strain $\left(\gamma_{t c}\right)$ the microstructure of soil changes irreversibly; soil stiffness changes permanently; a permanent pore-water pressure builds up in fully saturated cyclically shear loading in drained conditions, and for dry soil, partially saturated soil, or fully saturated soils with drainage allowed, a permanent volume change accumulates (Bai 2011). Vucetic (1994) determined the value of $\gamma_{t c}$ at which the ratio of the modulus to maximum modulus is proximately 0.65 . Therefore, for the analyzed soils, the average cyclic threshold strain is 2.80E-04 (sample A) and 3.86E03 (sample B). In terms of the average values of the reference shear strain $\left(\gamma_{r}\right)$, defined earlier in this work, for sample A it amounts $4.26 \mathrm{E}-04$. For sample $\mathrm{B}, \gamma_{r}$ is out of the range of testing strain.

In order to calculate the normalized shear modulus $\left(G / G_{\max }\right)$ of analyzed soils, the authors employed the earlier suggested modified hyperbolic equation (Eq. 1) - originally proposed by Darendeli (2001). The fittings parameters of this model are the reference strain $\left(\gamma_{r}\right)$, which was adopted here as $\gamma_{r}=4.26 \mathrm{E}-04$, and a curvature coefficient $(a)$, which 
a

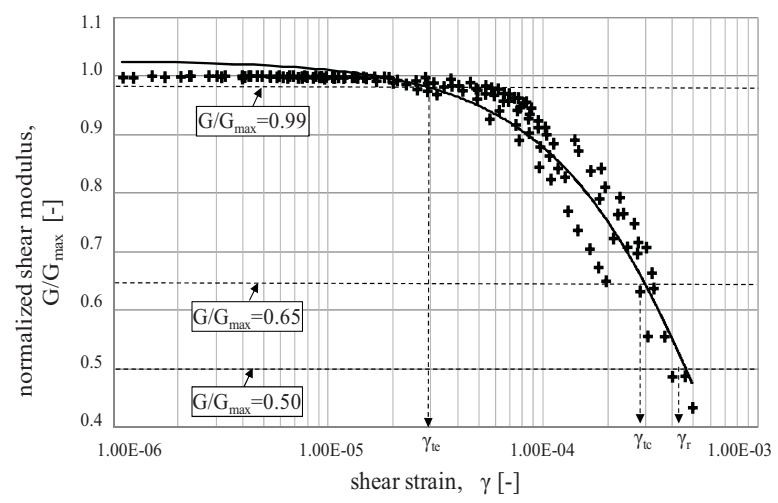

b

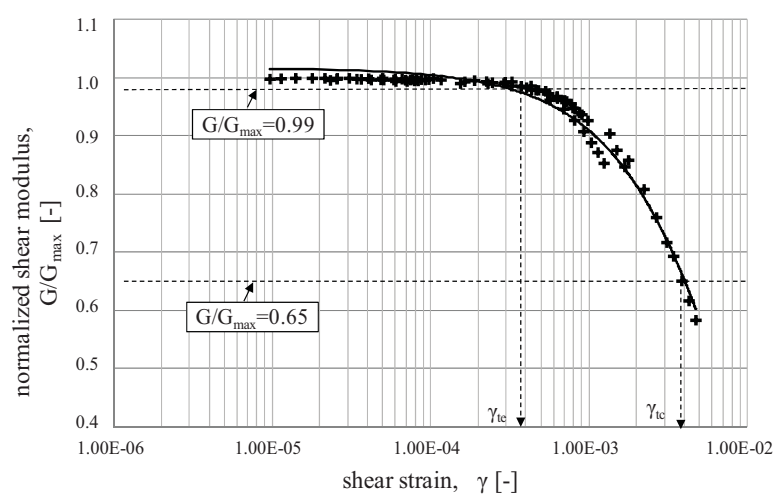

FIGURE 7. Variations of the normalized shear modulus with the shearing strain for sample (a) A and (b) B

was predicted using Menq (2003) proposition (Eq. 3) and also determined based on the RC tests using the errors analysis. Comparison of $G / G_{\max }-\log \gamma$ relationships between the RC tests and Menq's predictions for sample A are presented in Table 3.

Due to the small difference between the value of $a$, the authors assumed its independence from the $p$ ' variable and calculated its average value.

Comparing the $\mathrm{RC}$ tests results with Menq's prediction results, the first one are better than the second. The application of determined curvative parameter (a) based on the RC tests allows the better matching of the hyperbolic model to the measured values of $G / G_{\max }$. It gives as well $10 \%$ lower value of standard deviation $(S D)$ and approximately five times lower values of the average relative error $(A R E)$ and the root mean square error (RMSE). Thus, it is clear that Menq's proposal for use in the modified hyperbolic model suggested by Darendeli is not suitable for the tested soil. This conclusion is reflected in Figure 8.

Values of $G / G_{\max }$ calculated using Eq. 1, applying the fitting parameter $(a)$ summarized in Table 3, are comapred with measured values in Figure 8. In Figure $8 \mathrm{a}$, the plotted data points distribute 
TABLE 3. Fitting parameter $a$ for Eq. 1 under various mean effective stress from $R C$ tests and Menq's proposal with the errors analysis

\begin{tabular}{|c|c|c|c|c|c|c|c|c|c|c|c|}
\hline \multirow[b]{3}{*}{ 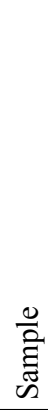 } & \multirow{3}{*}{ 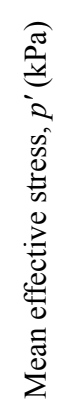 } & \multicolumn{10}{|c|}{ Modified Hyperbolic Relationship $G / G_{\max }=1 /\left[1+\left(\gamma / \gamma_{r}\right)^{\mathrm{a}}\right]$} \\
\hline & & \multicolumn{5}{|c|}{ from $\mathrm{RC}$ tests } & \multicolumn{5}{|c|}{ from Menq (2003) } \\
\hline & & 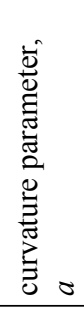 & 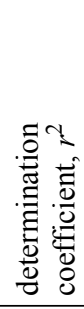 & 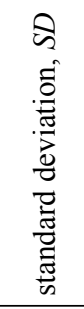 & 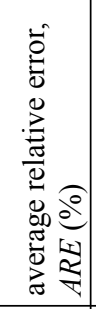 & 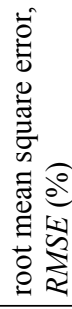 & 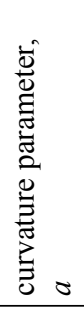 & 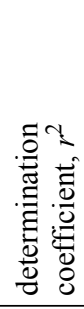 & 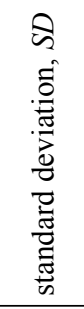 & 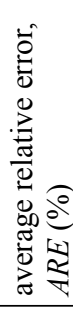 & 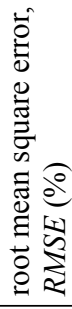 \\
\hline \multirow{6}{*}{ A } & 30 & 1.114 & 0.991 & 0.160 & 3.22 & 2.77 & 0.808 & 0.980 & 0.153 & 5.76 & 5.61 \\
\hline & 120 & 1.464 & 0.994 & 0.150 & 1.09 & 1.23 & 0.868 & 0.953 & 0.151 & 6.47 & 6.74 \\
\hline & 180 & 1.618 & 0.998 & 0.075 & 0.34 & 0.47 & 0.886 & 0.893 & 0.108 & 7.56 & 8.11 \\
\hline & 240 & 1.707 & 0.998 & 0.109 & 0.47 & 0.67 & 0.898 & 0.901 & 0.132 & 8.10 & 8.57 \\
\hline & 360 & 1.705 & 0.999 & 0.111 & 1.06 & 1.44 & 0.916 & 0.897 & 0.135 & 8.17 & 8.88 \\
\hline & 410 & 1.911 & 0.997 & 0.098 & 0.75 & 1.29 & 0.921 & 0.893 & 0.132 & 8.55 & 9.51 \\
\hline \multicolumn{12}{|c|}{ Average } \\
\hline & & 1.592 & 0.986 & 0.124 & 1.16 & 1.31 & 0.883 & 0.883 & 0.137 & 7.43 & 7.90 \\
\hline
\end{tabular}

quite evenly about the "measured-calculated" line, with very high calculated determination coefficient $r^{2}=0.9861$. In Figure 8b, however, greater scatter of data points is noticable, with $10 \%$ smaller $r^{2}$. When interpreating the first value of $r^{2}$, one point must be keep in mind, which is that the most of $G / G_{\max }$ data are concentrated around $0.8-1.0$, where error is inherently small, because of the normalization process. As a consequence, the $r^{2}$ value may not completely reflect the goodness-of-fit of the model used at lower values of $G / G_{\max }$.

\section{Nonlinear dynamic properties - damping ratio}

The nonlinear material damping ratios $(D)$ of silty clay soils were also measured during the RC-HA tests. These tests were performed in conjunction with the nonlinear shear modulus measurements after the RC-LA tests. The variations in $D$ with the shear strain $(\gamma)$ during loading and unloading process are shown in Figures 9 and 10 . It can be seen that $D$ for both tested samples increases with increasing $\gamma$. All material damping relationships fall in a narrow zone, with little spread shown in the $D-\log \gamma$ relationships, especially for strain not exceeding $1.00 \mathrm{E}-04$. The rate of increase decreases with the confining pressure or the mean effective stress. Testing scatter decreases with increasing $p$, this is contributed to better coupling between the tested sample and the top cap under higher pressure.

As illustrated in Figures 9 and 10, the authors received different highest values of the damping ratio; for sample A the 
a

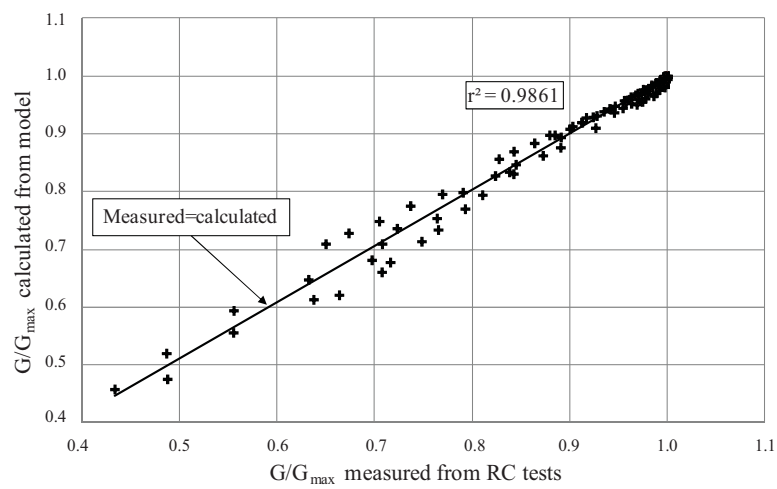

b

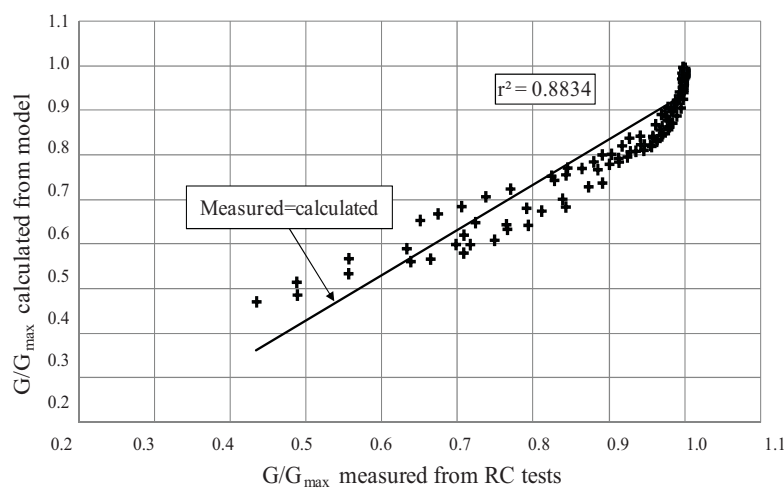

FIGURE 8. Comparison of measured and calculated $G / G_{\max }$ using a curvature coefficient calculated from (a) RC tests and (b) Menq's proposition

biggest $D=8.22 \%$ when $p^{\prime}=30 \mathrm{kPa}$, while for sample $\mathrm{B}$ the biggest $D=4.78 \%$ when $p^{\prime}=310 \mathrm{kPa}$. Moreover, the damping curves shift to a right lower position with increasing mean effective stress, which, in most cases means, the lower mean effective stress the higher damping ratio when shearing strain amplitude remains the same. For $\gamma=1.00 \mathrm{E}$ -04, for instance, the following $D$ were obtained: $D=2.65 \%$ for $p^{\prime}=30 \mathrm{kPa}$, $D=1.82 \%$ for $p^{\prime}=180 \mathrm{kPa}, D=1.61 \%$ for $p^{\prime}=410 \mathrm{kPa}$ (data apply to sample A). Also, $D$ increases on average $36.5 \%$ (sample A) and 88.3\% (sample B) over the range in $\gamma$ in the high-amplitude $\mathrm{RC}$ tests.
With respect to the unloading process, it is observed in Figure $9 \mathrm{~b}$ that the $D$ values are lower compared to these from loading stage. The differences between $D_{\text {loading }}$ and $D_{\text {unloading }}$ varies in the range from 3 up to $9 \%$ for the stress from 120 to $360 \mathrm{kPa}$, whereas the higher difference value $(\Delta \mathrm{G} \cong 9 \%)$ corresponds to $p^{\prime}=180$ and $240 \mathrm{kPa}$.

Figure 11, on the other hand, indicates the variation of the normalized damping ratio $\left(D / D_{\min }\right)$ with the shear strain of both analyzed samples. Similarly to the normalized shear modulus, the average value of the reference shear strain $\left(\gamma_{r, D}\right)$ was found. For sample $\mathrm{A}$ it 
a

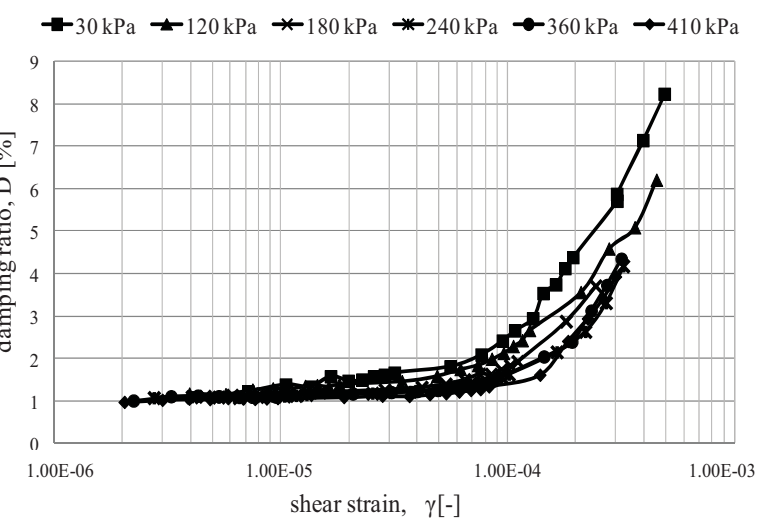

b

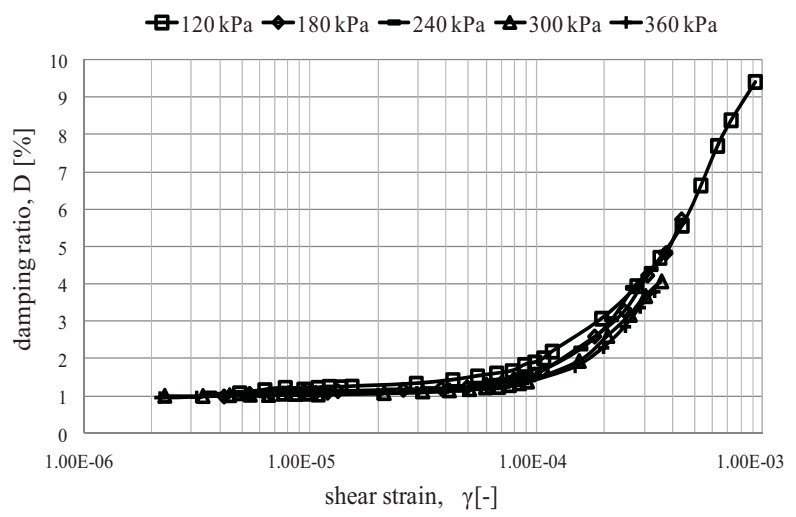

FIGURE 9. Damping ratio versus shear strain for sample A during (a) loading and (b) unloading process

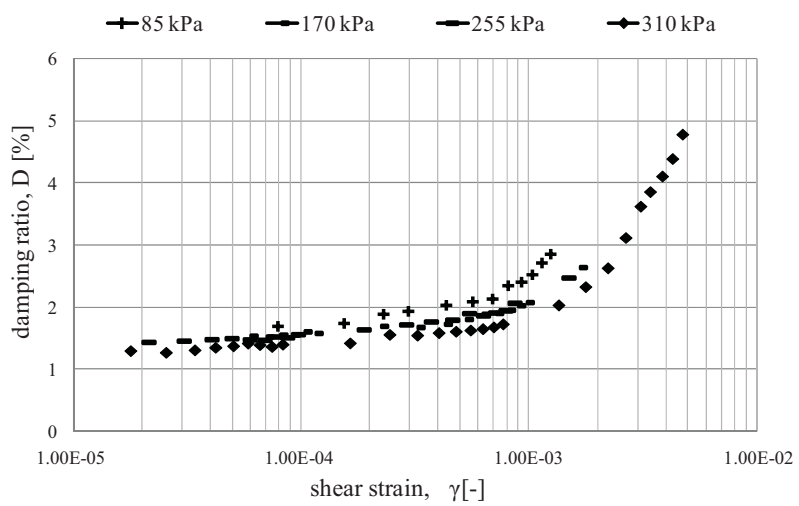

FIGURE 10. Damping ratio versus shear strain for sample B during loading process 
a

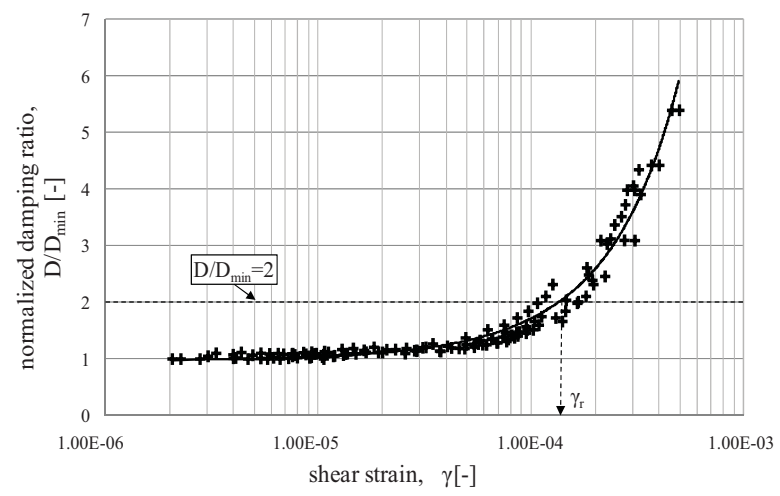

b

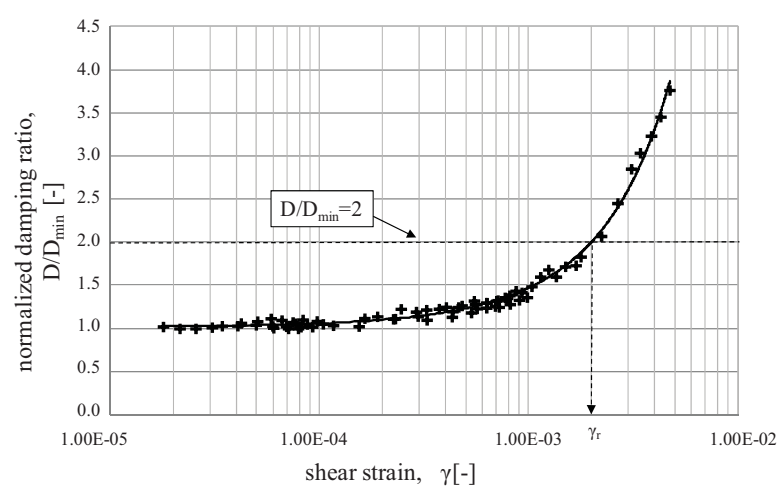

FIGURE 11. Variations of the normalized damping ratio with the shearing strain for sample (a) A and (b) B

amounts $1.46 \mathrm{E}-04$, when for sample B $\gamma_{r, D}$ is equal to $2.23 \mathrm{E}-03$.

One approach to modelling $D$ is relating it to the reference shear strain, in accordance with the previously proposed hyperbolic model (Eq. 4). For each sample, as well as for each mean effective stress, $D-\log \gamma$ relationship has been best-fit with Eq. 4 using the root-mean square error method. The resulting bestfit values of the parameter $b$, together with the results of the errors analysis are presented in Table 4.

As summarized in Table 4, the average values of $b$ of both tested specimens are comparable. There is a big difference in the value of $r^{2}$ for the best-fits to determine $b . r^{2}$ obtained for sample $\mathrm{B}$ shows
$99 \%$ adaption of the model to the analyzed data. For sample A, around $21 \%$ of differentiation in $D / D_{\min }$ is not explained by the hyperbolic model. In terms of the average relative error $(A R E)$ and the root mean square error (RMSE), it can be observed that for sample $\mathrm{B}$ the errors are about $3(A R E)$ and 6 times (RMSE) less than for sample A. Therefore, the proposed hyperbolic model seems to be in a good agreement with the tests results of sample B, but do not satisfactory represents the behaviour of sample A.

In order to observe and compare the normalized damping ratio $\left(D / D_{\min }\right)$, derived experimentally in the RCA and analytically using Eq. 4 of each specimen, Figure 12 was prepared. For sam- 
TABLE 4. Fitting parameter $b$ for Eq. 4 under various mean effective stress from RC tests with the errors analysis

\begin{tabular}{|c|c|c|c|c|c|c|}
\hline \multirow{3}{*}{ Sample } & \multirow{3}{*}{$\begin{array}{l}\text { Mean } \\
\text { effective } \\
\text { stress, } p^{\prime} \\
{[\mathrm{kPa}]}\end{array}$} & \multirow{2}{*}{\multicolumn{5}{|c|}{$\begin{array}{l}\text { Modified Hyperbolic Relationship } \\
\text { from RC tests }\end{array}$}} \\
\hline & & & & & & \\
\hline & & $\begin{array}{c}\text { curvature } \\
\text { parameter, } b\end{array}$ & $\begin{array}{l}\text { determination } \\
\text { coefficient } r^{2}\end{array}$ & standard deviation, $S D$ & $\begin{array}{l}\text { average relative } \\
\text { error, } A R E[\%]\end{array}$ & $\begin{array}{l}\text { root mean square } \\
\text { error, } R M S E[\%]\end{array}$ \\
\hline \multirow{6}{*}{ A } & 30 & 1.690 & 0.970 & 2.032 & 13.27 & 90.80 \\
\hline & 120 & 0.723 & 0.976 & 0.623 & 10.25 & 65.77 \\
\hline & 180 & 1.263 & 0.991 & 0.724 & 2.81 & 12.46 \\
\hline & 240 & 1.385 & 0.995 & 0.831 & 3.58 & 10.79 \\
\hline & 360 & 0.813 & 0.920 & 0.561 & 9.09 & 41.94 \\
\hline & 410 & 1.594 & 0.994 & 0.926 & 4.34 & 7.83 \\
\hline & Average & 1.245 & 0.785 & 0.950 & 7.22 & 38.26 \\
\hline \multirow{5}{*}{ B } & 85 & 1.106 & 0.978 & 0.195 & 2.34 & 3.95 \\
\hline & 170 & 1.299 & 0.992 & 0.217 & 1.60 & 2.74 \\
\hline & 255 & 0.960 & 0.984 & 0.201 & 1.84 & 2.77 \\
\hline & 310 & 0.974 & 0.990 & 0.699 & 4.91 & 16.57 \\
\hline & Average & 1.085 & 0.987 & 0.328 & 2.67 & 6.51 \\
\hline
\end{tabular}

ple A (Fig. 12a), more scatter points are clearly visible, which confirms the $r^{2}$ value showing only a satisfactory match of the model. In the case of sample B (Fig. 12b), however, the plotted data distribute equally about the "measuredcalculated" line. Similarly, as for the normalized shear modulus $\left(G / G_{\max }\right)$, the damping points are more concentrated between certain values $(1 \div 2 \%$ sample $A$, $1 \div 1.5 \%$ sample $\mathrm{B}$ ), and this suggests that even high $r^{2}$ may not reflects the goodness-of-fit of the recommended equation at higher values of $D$.

\section{CONCLUSIONS}

In this paper the low-amplitude and high-amplitude resonant column tests were performed in order to study the small-strain and the nonlinear dynamic properties of silty clay soils collected from the centre of Warsaw, district Śródmieście. The impact of factors, like the mean ef- fective stress $\left(p^{\prime}\right)$, the shear strain $(\gamma)$ and the unloading process, on the dynamic properties of these cohesive soils were recognized on two exemplary samples, $\mathrm{A}$ and $\mathrm{B}$. The authors implemented here the well-known modified hyperbolic model for the analysis of the $G / G_{\max }$ $-\log \gamma$ and $D / D_{\min }-\log \gamma$ curves. They presented as well the comparison of the $R C$ test results and Menq's prediction to show rather inconsistency of using Menq's equation for the analyzed specimens.

From the data described in this paper, the following conclusions may be drawn:

1. The dependence of the small-strain dynamic properties on the mean effective stress was well documented in this study. Growth of the smallstrain shear modulus $\left(G_{\max }\right)$, around $15-20 \%$ for both samples, and loss of the small-strain damping ratio $\left(D_{\min }\right)$, about $3-5 \%$ for sample $A$ and $11-$ $-13 \%$ for sample $B$, due to the in- 
a

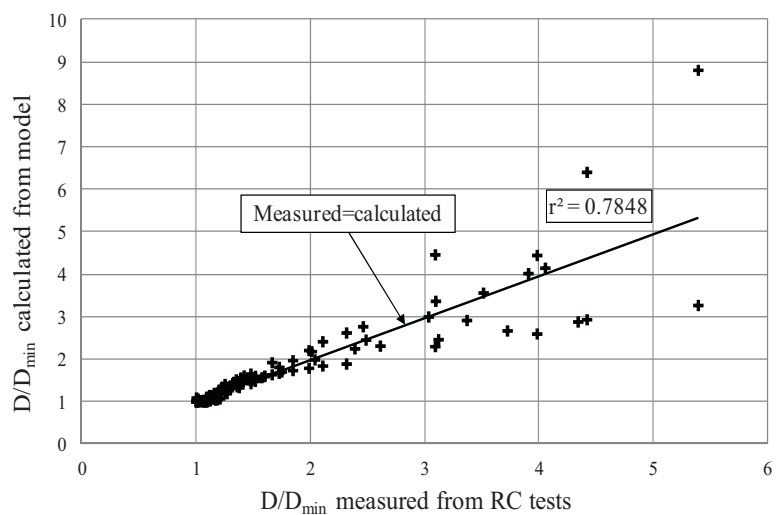

b

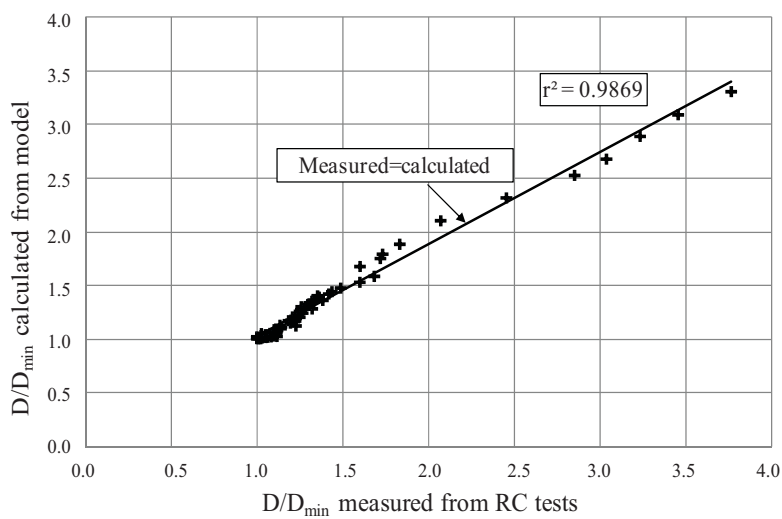

FIGURE 12. Experimentally against analytically derived values of $D / D_{\min }$ for sample (a) A and (b) B

crease in the effective stress were clearly observed, as seen in Table 2. The unloading caused a smaller growth in $G_{\max }$ with the decrease of $p$, which amounted from 4 to $9 \%$ with the decrease of $p$ '.

2. Loss of the shear modulus $(G)$ due to the increase in the applied shear strain was illustrated in the paper too. The shearing strain amplitude may have eliminated the influence of the mean effective stress on the shear modulus at very high strain level which proves the smaller distance in $G$ under various $p^{\prime}$. The $G$ values from the unloading stage were from 10 up to $30 \%$ greater than those from the loading process.

3. The average elastic threshold strain $\left(\gamma_{t e}\right)$ for sample A was $2.86 \mathrm{E}-05$ and for sample B - 3.56E-04. Moreover, as noted earlier in this paper, for sample $B$ the linear elastic range is bigger than for sample A, which may have indicated greater stiffness of sample B. The average cyclic threshold strain $\left(\gamma_{t c}\right)$ were found as well and amounted 2.80E-04 (sample A) and 3.86E-03 (sample B). The average value of the reference shear strain $\left(\gamma_{r}\right)$ was obtained only for sample $\mathrm{A}$, in the amount of 4.26E-04. 
4. Hyperbolic model, modified from Darendeli (2001), was successfully used in this paper in order to study the nonlinear shear modulus behaviour of silty clay soils. Compared to the RC tests, Menq's equations gave worse results for predicting the nonlinear shear modulus behaviour. This conclusion is reflected in Figure 8.

5. The material damping of both tested soils increased with increasing $\gamma$. For sample A, $D$ increased by an average of $36.5 \%$, whereas for sample B of $88.3 \%$, over the range in $\gamma$ in the highamplitude $R C$ tests. The rate of this increase decreased with the mean effective stress. Furthermore, it was observed that the lower mean effective stress the higher damping ratio when shearing strain amplitude remained the same. The unloading caused a smaller growth in $D$ with increasing shear strain, which was in the range from 3 to 9\% (Figs 9, 10).

6 . The average value of the reference shear strain $\left(\gamma_{r, D}\right)$, in respect to the material damping ratio, was found too. For sample A it amounted 1.46E-04 , when for sample $\mathbf{B} \gamma_{r, D}$ was equal to $2.23 \mathrm{E}-03$.

7. Similarly as for the nonlinear shear modulus, Darendeli's modified hyperbolic model was applied again to study the nonlinear material damping ratio behaviour of silty clay soils. The proposed hyperbolic model seemed to be in a good agreement with the tests results of sample B, but did not satisfactory represent the behaviour of sample A. A great scattering of points, as see in Figure 12, confirmed this observation.
To summarize, the authors would like to emphasize that obtained dependences of e.g. the shear modulus values on the strain values, analyzed here from the point of view of dynamic loading, should not be limited only to the dynamic problems. Although, they did not examine the soil behaviour under static loading, it seems that the similar characteristics can be obtained by static loading, for the same strain range (Georgiannou $i$ in. 1991, Jastrzębska 2010).

\section{REFERENCES}

ASTM D 4015-92, 2000: Standard Test Methods for Modulus and Damping of Soils by the Resonant-Column Method. American Society for Testing and Materials. Annual Book of ASTM Standards, ASTM International, West Conshohocken, PA.

BAI L. 2011: Preloading effects on dynamic sand behavior by resonant column tests. $\mathrm{PhD}$ Dissertation. Technische Universität Berlin, Berlin.

CARRARO J.A.H. 2015: Stiffness degradation and damping of carbonate and silica sands. In: Frontiers in Offshore Geotechnics III. Meyer (Ed.). Taylor \& Francis Group, London, 1179-1183.

CASCANTE G., VANDERKOOY J., CHUNG W. 2005: A new mathematical model for resonant-column measurements including eddy-current effects. Canadian Geotech. J. 42 (1), 121-135 doi 10.1139/t04-073.

DARENDELI B.M. 2001: Development of a new family of normalized modulus reduction and material damping curves. $\mathrm{PhD}$ Dissertation. The University of Texas at Austin. USA.

DAS M.B. 1993: Principles of Soil Dynamics. Boston: PWS-KENT Publishing Company. 
EN 1997. Eurocode 7: Geotechnical Design - General Rules, European Prestandard ENV.

GABRYŚ K. 2014: Charakterystyki odkształceniowe wybranych gruntów spoistych [Defermation characteristics of selected cohesive soils]. PhD Dissertation. Warsaw University of Life Sciences - SGGW, Faculty of Civil and Environmental Engineering, Warsaw (in Polish).

GABRYŚ K., SAS W., SZYMAŃSKI A. 2013: Kolumna rezonansowa jako urządzenie do badań dynamicznych gruntów spoistych [Resonant Column Apparatus as a device for dynamic testing of cohesive soils]. PN IKS - Eng. Envi. Sci. 22 (1), 59, 3-13.

GABRYŚ K., SAS W., SOBÓL E. 2015: Small-strain dynamic characterization of clayey soil from Warsaw. Acta. Sci. Pol., Arch. 14 (1), 55-65.

GASPARRE A., HIGHT D.W., COOP M.R., JARDINE R.J. 2014: The laboratory measurement and interpretation of the small-strain stiffness of stiff clays. Géotechnique 62 (12), 942-953.

GDS Resonant Column, 2010. The GDS Resonant Column System Handbook.

GEORGIANNOU V.N., RAMPELLO S., SILVESTRI F., 1991: Static and dynamic measurements of undrained stiffness on natural over consolidated clays. Proceedings of the $10^{\text {th }}$ ECSMEF, Florence, 1, 91-95.

HARDIN B.O., DRNEVICH V.P. 1972: Shear Modulus and Damping in Soils: Design Equations and Curves. J. Soil Mech. Found. Div. ASCE 98 (7), 667-692.

HARDIN B.O., RICHART F.E. 1963: Elastic Wave Velocities in Granular Soils. J. Soil Mech. Found. Div. ASCE, 89(1), 33-65.

HEAD K.H. 1986: Manual of soil laboratory testing. London, Pentech Press.

ISENHOWER W.M.. STOKOE K.H. II 1981: Strain-rate dependent shear modulus of San Francisco Bay mud. International Conference on Recent Advances in Geotechnical Earthquake Engineering and Soil Dynamics, St. Louis, Missouri, Univ. of Missouri-Rolla.

JASTRZĘBSKA M. 2010: Badania zachowania się gruntów spoistych poddanych obciążeniom cyklicznym w zakresie małych odkształceń. Wydawnictwo Politechniki Śląskiej, Gliwice.

KACAR O. 2014: Building a framework for predicting the settlements of shallow foundations on granular soils using dynamically measured soil properties. $\mathrm{PhD}$ Dissertation. The University of Texas at Austin, USA.

KHAN Z.H., CASCANTE G., El NAGGAR M.H. 2008: Linearity of the first torsional mode of vibration and base fixidity in resonant column. ASTM, Geotech. Test. J. 31 (1), 587-606.

KRAMER S.L. 1996: Geotechnical Earthquake Engineering. Prentice-Hall International Series in Civil Engineering and Engineering Mechanics. Upper Saddle River, New Jersey.

MENQ F.Y. 2003: Dynamic Properties of Sandy and Gravelly Soils. Ph.D. Dissertation. University of Texas at Austin, USA.

QIAN X., GRAY D.H., WOODS R.D. 1993: Voids and Granulometry - Effects on Shear Modulus of Unsaturated Sands. $J$. Geotech. Eng. ASCE 119 (2), 295-314.

SAS W., GABRYŚ K. 2012: Laboratory measurement of shear stiffness in resonant column apparatus. Acta Sci. Pol., Arch. 11 (4), 29-39.

SAS W., GABRYŚ K., SZYMAŃSKI A. 2015a: Effect of time on dynamic shear modulus of selected cohesive soil of one section of Express Way No S2 in Warsaw. Acta Geophys. 63, 2, 398-413.

SAS W., GABRYŚ K., SOBÓL E., SZYMAŃSKI A. 2015b: Stiffness and damping of selected cohesive soils based on dynamic laboratory tests. LXI Konferencja Naukowa Komitetu Inżynierii Lądowej i Wodnej PAN oraz Komitetu Nauki PZITB - Materiały konferencyjne, 325-332. 
SHEN C.K., LI X.S., GU Y.Z. 1985: Microcomputer Based Free Torsional Vibration Test. J. Geotech. Eng., ASCE 111 (8), 971-986.

SOBÓL E., SAS W., SZYMAŃSKI A. 2015: Zastosowanie kolumny rezonansowej do określenia reakcji gruntów drobnoziarnistych obciążonych dynamicznie [The use of resonant column to determine the response of dynamically loaded fi ne grained soils]. PN IKS 24 (2), 68, 133-144 (in Polish).

TANAKA Y., KUDO K., NISHI K., OKAMOTO T. 1994: Shear modulus and damping ratio of gravelly soils measured by several methods. In: Pre-Failure Deformation of Geomaterials. T. Mitachi, S. Miura (Eds). Vol. 1. A.A. Balkema, Rotterdam, 47-53.

VUCETIC M. 1994: Cyclic Threshold Shear Strains in Soils. J. Geotech. Eng., ASCE 120, SM12, 2208-2228.

WANG Y. 2015: Dynamic Properties of Fine Liquefiable Sand and Calcareous Sand from Resonant Column Testing. MSc. Dissertation. University of Texas at Austin, USA.

Streszczenie: Nieliniowe dynamiczne właściwości itu pylastego z okolic Warszawy. W niniejszej pracy, zaprezentowano dynamiczne właściwości próbek iłu pylastego $\mathrm{w}$ zakresie małych i średnich odkształceń, otrzymane na podstawie dwóch rodzajów badań w kolumnie rezonansowej $(K R)$, tj. o niskiej i wysokiej amplitudzie drgań, przy różnych wartościach średniego naprężenia efektywnego $\left(p^{\prime}\right)$. Badane próbki pochodziły $\mathrm{z}$ centrum miasta Warszawy, z dzielnicy Śródmie- ście. Jako pierwsze badania, przeprowadzono te o niskiej amplitudzie drgań (odkształcenie poniżej $0,001 \%$ ), a następnie badania o wysokiej amplitudzie drgań, przy odkształceniach większych niż $0,001 \%$. Głównym celem wykonanych badań było uzyskanie nieliniowej charakterystyki dynamicznych właściwości iłu pylastego. Oprócz tego, podczas badań o niskiej amplitudzie drgań, otrzymano informacje dotyczące wskaźnika thumienia analizowanych próbek. Wyniki pokazują, że wzrost odkształcenia postaciowego $(\gamma)$ powyżej granicy sprężystości $\left(\gamma_{t e}\right)$ powoduje zmniejszenie wartości modułu ścinania $(G)$ i znormalizowanego modułu ścinania $\left(G / G_{\max }\right)$ oraz równoczesny wzrost wartości wskaźnika tłumienia $(D)$ i znormalizowanego wskaźnika tłumienia $\left(D / D_{\min }\right)$. $\mathrm{W}$ pracy przedstawiono również pewne równania empiryczne służące oszacowaniu znormalizowanego modułu ścinania i wskaźnika thumienia iłu pylastego. Prezentowane równania bazują na zmodyfikowanym modelu hiperbolicznym, jak również analizie statystycznej wyników pomiarów z kolumny rezonansowej. W artykule omówiono także wpływ procesu odciążania na dynamiczne właściwości badanego materiału.

MS, received June 2016

\section{Authors' address:}

Katarzyna Gabryś

Katedra Geoinżynierii

Wydział Budownictwa i Inżynierii Środowiska SGGW

ul. Nowoursynowska 159, 02-776 Warszawa

Poland

e-mail: katarzyna_gabrys@sggw.pl 